\title{
The Cosmogony of Hindu Pilgrimage
}

\author{
Masaaki Fukunaga
}

\section{Introduction.}

Hindu Pilgrimage practice in India takes many forms. It is very difficult to identify any common behaviour or ideas to all pilgrim who journeying to sacred places. Two significant features which do recur consistently are sacred places and the act of journeying itself.

A large number of Hindu pilgrims from whole of the country are visiting to Varanasi/ Kashi in everyday, where is one of the most famous Hindu sacred place in India. Varanasi is holy city and city of Śiva.

Siva is considered as a god without any form or attributes, and further stands for all knowledge. His name Śambhu is derived from Svayambhuva which reflects the meaning of self-born. It has been realized in ancient past that he was at the bottom of everything that is moving, he was called Isvara or i-chara ( $i=$ this, and char $a=$ to move) [Pillai, 1959, p. 11]. It is the reason why various forms of Siva are transposed in Varanasi as the form of Isvara (as suffix to the various forms of Siva), and a lingam has been installed there to honour that form.

It's a popular saying that every piece of stone has divinity of Siva in Kashi. This proverb clearly indicates a large number of Śiva lingams, and also peoples' strong belief to worship Siva as the patron deity of the city. In the processes of humanization and sanctification all human performances are added to Lord Siva, therefore worship of various lingams is associated to different motives.

There are many legends and Puranic descriptions about the origin of worship of Siva in anthropomorphic and ithyphallic form, usually as the stylized lingam [Morinis, 1984, pp. 27-30].

The Siva lingam consists of three parts: a square at the bottom, an octagon 
in the centre, and a cylinder with special end at the top. Symbolically speaking, the square represents Brahmā, the create; the octagon represents Vishnu, the preserver; the round portion which vanishes at the top even without a point represents Siva, the destructor. As so the lingam integrates evalution, existence and involuation, i. e. sristhi, stiti, and samhāra [Pillai, 1959, pp. 19-20]. This number three also be compared with Śiva's triśula-three pronged spear, Trident. These are symbolized in the landscape of Varanasi with the three sacred segments, each having antargriha route and the patron deity: Viśveśvara in the centre, Omkäreśvara in the north, and Kedāreśvara in the south. It is the perception that Varanasi/ Kashi is believed to be settled on the triśüla.

\section{Typology of Śiva Lingams.}

According to the Skanda Purāna-Kāsi Khanda $(97,261,269,280)$, there are exist 511 Siva lingams in Kashi region [Sukul, 1977, p. 122]. Referring to typology in Kashi, a five-tier hierarchy of lingams, famous for their various niches of spiritual magnetism can be identified:

1. Self-born lingams (Svayambhuva).

2. Lingmas installed by the Hindu Planets and Gods.

3. Lingams installed by the Great Saints.

4. Lingams installed by Śiva Ganas.

5. Spatially Transposed Lingams.

The Universal personality of Siva is represented with number five which shows wholeness. The five faces of Siva originated out of the formless Absolute (sūnya), and they are source of the five saktis and five kalās (energies and their subtle material manifestations) from which the world is created. Each face is connected with certain meaning of power, specific mantra, direction, colour and the five basic elements of the organism [Vail, 1985, p. 124, 183]. Therefore, Siva is regarded as Panchamukha (five-headed) with different symbolic colours for different forms, and each form is installed in Varanasi separately. The merit and glories of these five forms are given in the Linga Purana (I. 23, 18-23). Even the mantra to please Siva, panchākshari (Namah Śivāya), is related to the five forms thus its muttering represents the absolute entity of the whole universe. 


\section{Reflection on Cosmogony.}

The Puranic literature describe Varanasi as the first deity after the great cosmic dissolution (mahäpralaya) which later developed as resort of Lord Śiva [Parry, 1981, p. 331]. This was first perceived long ago and promoted the installation of enormous forms of Siva as Iśvara (the Universal Lord) in the sacred topography of Varanasi.

The concept of spatial transposition and the cosmogony of the yātrās (routes of pilgrimage), can be represented with model of a series of concentric circles with sansity increasing as one moves towards the centre. In totaly there are seven layers of main circles of which each is intersected at eight places by radials. The number eight signifies the eight directions, and seven, the seven layers in the atmosphere. Seven layers and eight directions intersect each other at points where shrines of Ganeśa in the Vinãyaka are established [Sigh Rana, 1985]. This elephant-headed deity is the son of Siva and considered as Lord of Obstacles and Gurdian of Thresholds who populary exists on doorways and temple gateways [Getty, 1936 ; Courtright, 1985]. According to another interpretation Ganeśa is considered 'leader of the army'. Moreover, he is also known as Vighneśvara, "the god who removes not only the jungle in front of the marching soldiers, but all that obstructs his devotees" [Pillai, 1959, p. 14]. With this perception the peopling and territorialization of Kashi can be highlighted. The existence of first layer of eight Vināyakas on the Panchakroshi route, i.e. Arka (Lolārk), Durg (Durgakund), Bhima Chaṇda (Bhimchandi), Delhi, Uddaṇạa, Pāśpāni, Kharva (Adi Keshva Ghat) and Siddha Vināyakas, may be interpreted as the outermost limit of the territory established through forest clearning, therefore the first ring of eight Vināyakas are lying there.

The number three, four and five are again represented with various layers of yātrās: three with Avimukta, Negara Pradaksin̄ā and Panchakroshi; four additionally including Antargriha (i.e. Viśveśvara Antargriha); five in addition to above four Brinhada Panchakroshi route. These numbers may be symbolized with trident (three prongs), four arms, and five-headed image of Siva. This again shows that Siva is an universal God having control over three realms, four di- 
rections and five elements. It is the form of sacred topography in Varanasi/Kashi which promotes its character towards "wholeness".

\section{Conclusion.}

As we analysing Siva lingams and searching their linkages with various types of routes of pilgrimages, Hindu's synthetic view of "expanding universe" and "universe within universe" would be projected clearly.

The nature of expansion is marked from the centre of the patron deity, Viśveśvara to the layers of $y \bar{a}$ trās surrounding him. Further in reference to shrinking process, one can metaphorically analyse "universe within universe". This interactional system of expanding-shrinking reflects the polythetic character of Indian religion, what Max Müller termed as Kathenotheism [Eck, 1982, p. 40].

This notion is practised by the Varanasi dwellers through worshipping one supreme (Śiva) but along with all other gods together, as they are called as bahudevapūjakas (worshippers of so many gods together).

\section{[References]}

1) Bharati, A., 1970, "Pilgrimage sites and Indian civilization". In J. W. Elder (ed.). Chapters in Indian Civilization, Iowa, Kendell/ Hunt. pp. 85-126. 2) Courtright. P. B., 1985, Ganeśa : Lord of obstacles, Lord of Beginnings. New York, Oxford University Press. 3) Eck, D. L., 1982, Banaras : City of Light. New York. Alfred Knopf Publishers. 4) Getty, A. 1936, Ganesa, a Monograph on the elephants faced God. Oxford, Clerendon Press. 5) Morinis, E. A. 1984, Pilgrimage in the Hindu Tradition A Case study of Weat Bengal. Delhi, Oxford University Press. 6) Parry, J. P., 1981, "Death and cosmogony in Kashi", Contribution to Indian Sociology. N. S. 15 (1-2), pp. 337-365. 7) Pillai, G. K., 1959, Hindu Gods and Hidden Mysteries. Allahabad, Kitab Mahal. 8) Singh Rana P. B., 1985, Varanasi : Glimpses of Religious Personality \& Development Plan. Varanasi, Tara Book Agency. 9) Spellman, J. W., 1962, "The Symbolic significance of number twelve in ancient India", Journal of Asian Studies. 22 (1), pp. 79-88. 10) Sukul, K. N. 1977, The Glory of Varanasi ; Varanasi Vaibhava (in Hindi). Patna, Bihar Rastrabhasha Parisad. 11) Vail, L. F., 1985, "Founders, Swamis and Devotees: Becoming Divine in North Karnataka", In J. P. Waghorne and N. Cutter (Ed.), Gods of Flesh/ Gods of Stone. Chamberslourg, Anima Publications. pp. 123-140.

(Lecturer, Takushoku University) 